\section{ЛІТЕРАТУРА}

1. Наказ МОЗ України від 03.02.09 № 55 «Про затвердження протоколів лікування дітей 3 ендокринними захворюваннями». Додатки.

2. Наказ МОЗ України від 27.04.2006 № 254 «Про затвердження протоколів надання медичної допомоги дітям за спеціальністю «Дитяча

Дата надходження до редакції 09.11.2018 p. ендокринологія». Протокол надання медичної допомоги дітям, хворим на ожиріння.

3. Weiss R. Childhood Metabolic Syndrome Must we define it to deal with it? / R. Weiss // Diabetes Care. 2011. - Vol. 34, N. Suppl. 2. - 171-176.

https://doi.org/10.24026/1818-1384.4(64).2018.150166

\title{
ЕФЕКТИВНІСТЬ МУЛЬТИМОДАЛЬНОЇ АНАЛГЕЗІЇ У ПАЦІЕНТІВ ІЗ ЗАХВОРЮВАННЯМ ЩИТОПОДІБНОЇ ЗАЛОЗИ
}

\author{
О.О. Сфімова, С.О. Тарасенко, М.В. Кунатовський \\ Украйнський науково-практичний центр ендокринної хірургї, трансплантаиії \\ ендокринних органів і тканин МОЗ України
}

\begin{abstract}
Актуальність. Мультимодальна (збалансована) аналгезія $\epsilon$ необхідним компонентом периопераційного анестезіологічного менеджменту для зниження насамперед побічної дії наркотичних (опіоїдних) анальгетиків, яка може заважати швидшому відновленню пацієнтів у післяопераційному періоді.

Збалансована (мультимодальна) аналгезія (ЗММА) передбачає одночасне використання двох або більше анальгетиків, що мають різні механізми дії і дозволяють досягти адекватного знеболення при мінімумі побічних ефектів, властивих призначенням великих доз одного анальгетика в режимі монотерапії.
\end{abstract}

Додавання регіональних методів знеболення (білатеральна блокада поверхневого шийного сплетіння - ББПШС) в комплекс ЗММА дозволяє знизати рівень застосування опіатів та покращити перебіг раннього післяопераційного періоду при виконанні тиреоїдектомій [1].

Мета: Оцінка ефективності комплексу ЗММА на тлі загальної анестезії севофлураном у пацієнтів 3 раком щитоподібної залози, яким виконується тиреоїдектомія в умовах спеціалізованого ендокринологічного центру.

Матеріали та методи. На базі наукового відділу ендокринної хірургії Українського науковопрактичного центру ендокринної хірургії, трансплантації ендокринних органів і тканин МО3 України було включено 96 пацієнтів в дослідження. Комплекс 3ММА включав у себе премедикацію за 25-30 хвилин за принципом pre-emptive analgesia (внутрішньовенне введення дексаметазону 4-8 мг, НПЗП з ліпофільними властивостями декскетопрофену 50 мг) та ББПШС 0,5\% розчином бупівакаїну по 8,0-10,0 мл (40-50 мг) з кожної сторони, а також внутрішньовенне введення метоклопраміду 20 мг. Цей комплекс ЗММА був застосований 47 пацієнтам 3 раком щитоподібної залози, які склали групу збалансованої аналгезії (група 3АС). Групу контролю (група К-С) склали 49 хворих 3 раком щитоподібної залози, яким виконувались тиреоїдектомії за традиційною в клініці методикою анестезіологічного забезпечення без застосування ББПШС та введення НПВП до розрізу. Оперативні втручання виконувались вумовахзагальноїанестезії із ШВЛ у вигляді низько-потокової інгаляційної анестезії севофлураном в групі К-С та мінімальнопотокової інгаляційної анестезії в групі ЗА-С. Аналгетичнийкомпонентзабезпечувавсявведенням фентанілу. Традиційна методика анестезіологічного забезпечення в групі К-С включала премедикації шляхом внутрішньом'язового введення 1,0 мл Омнопону $3 \mathrm{H} \quad 3 \quad 1 \%$ розчином димедролу 1,0 мл за 30-40 хвилин до початку операції; 3 антиеметичною метою на початку операції призначали метоклопрамід внутрішньовенно в дозуванні 10 мг. В післяопераційному періоді в групі ЗА використовувалось знеболення за принципом preventive analgesia [2]: внутрішньовенно вводився декскетопрофен кожні 8 годин протягом 2 діб. Парацетамол або метамізол натрію в дозуванні 1000 мг вводилися внутрішньовенно кожні 12 годин. В групі К застосовувалися морфін 10 мг через 
3-4 години після операції, декскетопрофен або метамізол натрію через 4-6 годин після морфіну.

Виконувалась оцінка аналгетичного компонента анестезії та рівня післяопераційного болю за ВАШ. Частота виникнення післяопераційної нудоти і блювання (ПОНБ) оцінювалась за шкалою [3], де 0 = відсутні нудота і/або блювання, 1 = нудота, 2 = позиви до блювання, 3 = блювання). Важка ПОНБ оцінювалась як сумарна частота показників 2 и 3.

Статистичну обробку одержаних даних проводили за допомогою програмного забезпечення Statistica 10.0 (StatSoft Inc., США) 3 використанням параметричних і непараметричних методів.

Результати. Аналізуючи данні, було відмічено, що загальне споживання фентанілу за операцію було найнижчим в групі ЗА-С $(283,4 \pm 12,4$ мкг за

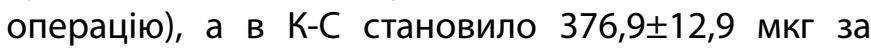
операцію. Таким чином, нами виявлено, що базова анестезія севофлураном 3 додаванням ББПШС в групі ЗА-С сприяє достовірно меншому споживанню фентанілу, ніж в групі К-С при моноанестезії севофлураном. Впровадження комплексу ЗММА із застосуванням ББПШС, дексаметазону, декскетопрофену мало суттєвий позитивний вплив на застосування наркотичних анальгетиків в післяопераційному періоді. Так, в групі ЗА-С вдалося повністю відмовитися від застосування наркотичних анальгетиків в післяопераційному періоді, тоді як в групі К-С вони були застосовані для знеболення протягом першої доби відповідно у 91,3\% хворих (достовірна різниця між групами ЗММА та контролю ( $<<0,05)$ за критерієм Пірсона) у вигляді внутрішньом'язової ін'єкції морфіну або омнопону. Також було відмічено, що рівень болю за ВАШ через 3 години після закінчення операції був

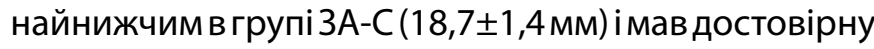
( $p<0,05)$ різницю з відповідним показником у групі

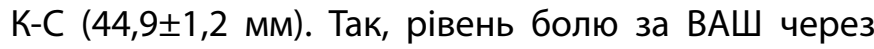
3 години в групі ЗА-С був нижчим на 58,4\%, ніж в групі К-С. Рівень болю за ВАШ був вищим в групі К-С, ніж в групі ЗА-С. Було відмічено, що загальна сума балів за шкалою ПОНБ була достовірно ( $p<0,05)$ нижчою в групі 3А-С $(0,41 \pm 0,11)$ порівняно з групою K-C $(0,92 \pm 0,12)$. Ми вважаємо, що зниження частоти ПОНБ в групі ЗА-С зумовлено достовірно нижчим рівнем болю, який $є$ одним із тригерів нудоти та блювання [4], зменшенням інтраопераційного застосування опіоїдів та повною відмовою від їх використання в післяопераційному періоді, обов'язковим включенням в комплекс поєднання
ББПШС і премедикації «на столі» із застосуванням дексаметазону та декскетопрофену, введення метоклопраміду перед індукцією анестезії.

\section{ВИСНОВКИ}

1. Інтраопераційне споживання анальгетиків, зокрема фентанілу, статистично значимо ( $<<0,05)$ нижче при застосуванні поєднаної інгаляційної анестезії севофлураном 3 додаванням 3МMA із ББПШС порівняно з моноанестезією севофлураном.

2. Комбінація декскетопрофену 3 інгібіторами ЦОГ-3 (парацетамолом або метамізолом) в групі ЗА-С підтримувала тривалу анестезуючу та аналгетичну дію ББПШС і давала змогу відмовитися від наркотичних анальгетиків у післяопераційному періоді.

3. Комплекс ЗММА із ББПШС, дексаметазоном та декскетопрофеном був більш ефективний, ніж традиційні методики багатокомпонентного знеболення в контрольній групі наркотичними та ненаркотичними анальгетиками. Група ЗА-С мала найкращий рівень післяопераційного знеболення, достовірно ( $p<0,05)$ менший показник болю за ВАШ в перші 6 годин порівняно з групою контролю.

4. Застосування комплексу ЗММА дає покращення показників ПОНБ - достовірне зниження частоти клінічно значущих ПОНБ з 26,0\% в групі К-С до 11,3\% в групі 3А-С.

Ключові слова: збалансована (мультимодальна) аналгезія, щитоподібна залоза.

\section{ЛІТЕРАТУРА}

1. Andrieu G, Amrouni $H$, Robin $E$, et al. The analgesic efficacy of bilateral superficial cervical plexus block administered before thyroid surgery under general anesthesia. British Journal of Anaesthesia. 2007; 6(2):147-149.

2. Козачок Н.Н., Селюк М.Н. Лидер XXI века в лечении болевого синдрома.// Український Медичний Часопис. - 2010. - № 3 (77). - С. 55-58.

3. Sonner JM, Hynson JM, Clark O, Katz JA. Nausea and vomiting following thyroid and parathyroid surgery. Journal of Clinical Anesthesia. 1997 Aug; 9(5):398402.

4. Гавриленко Г.В. Совершенствование антиэметического компонента анестезии при операциях на щитовидной железе: автореф. дис. канд. мед. наук: 14.01.20 / Гавриленко, Геннадий Васильевич; Министерство здравоохранения и социального развития Российской Федерации. Воронеж, 2012. - 17 с. 